\title{
Stability of $\mathrm{ZnAl}_{2} \mathrm{O}_{4}$ Catalyst for Reverse-Water-Gas-Shift Reaction (RWGSR)
}

\author{
Oh-Shim Joo* and Kwang-Deog Jung \\ Eco-Aano Research Center, Korea Institute of Science and Technologv. Cheongrvang P.O. Box 131. Seoul 130-650. Korea \\ Received May 13, 2002

\begin{abstract}
Reverse-Water-Gas-Shift reaction (RWGSR) was carried out over the $\mathrm{ZnO} . \mathrm{Al}_{2} \mathrm{O}_{2}$. and $\mathrm{ZnO} / \mathrm{Al}_{2} \mathrm{O}_{3}$ catalysts at the temperature range from 400 to $700^{\circ} \mathrm{C}$. The $\mathrm{ZnO}$ showed good specific reaction activity but this cataly st was

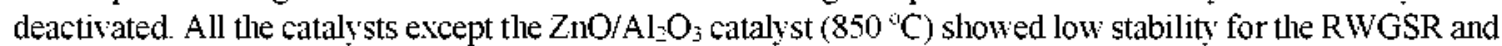
was deactivated at the reaction temperature of $600^{\circ} \mathrm{C}$. The $\mathrm{ZnO} / \mathrm{Al}_{2} \mathrm{O}_{3}$ catalyst calcined at $850^{\circ} \mathrm{C}$ was stable during 210 hrs under the reaction conditions of $600^{\circ} \mathrm{C}$ and $150.000 \mathrm{GHSV}$, showing CO selectivity of $100 \%$ even at the pressure of $5 \mathrm{~atm}$. The high stability of the $\mathrm{ZnO} / \mathrm{Al}_{2} \mathrm{O}_{3}$ catalyst $\left(850^{\circ} \mathrm{C}\right.$ ) was attributed to the prevention of $\mathrm{ZnO}$ reduction by the formation of $\mathrm{ZnAl}_{2} \mathrm{O}_{4}$ spinel structure. The spinel structure of $\mathrm{ZnAl}_{2} \mathrm{O}_{4}$ phase in the $\mathrm{ZnO} / \mathrm{Al}_{2} \mathrm{O}_{3}$ catalyst calcined at $850^{\circ} \mathrm{C}$ was confirmed by XRD and electron diffraction.
\end{abstract}

Key Words : RWGSR. Reducibility. Stability, Spinel

\section{Introduction}

The conversion of $\mathrm{CO}_{2}$ into chemical resources has been attempted by several methods to mitigate the greenhouse effects. ${ }^{l-4}$ Especially. the catalytic hydrogenation of $\mathrm{CO}_{2}$ to form methanol is one of the efficient processes being able to treat a large quantity of $\mathrm{CO}_{2}$ and the produced methanol can be consumed in the conventional chemical industry. We have reported CAMERE (Carbon Dioxide Hydrogenation to Form Methanol ria a Reverse-Water-Gas-Shift Reaction) process to convert $\mathrm{CO}_{2}$ into methanol. which consists of a reverse-water-gas-shift reaction (RWGSR) and a methanol synthesis reaction. ${ }^{5}$ In this report. carbon dioxide and hyddrogen were converted to $\mathrm{CO}$ and $\mathrm{H}_{2} \mathrm{O}$ by RWGSR and then the mixture gas of $\mathrm{CO} / \mathrm{CO}_{2} / \mathrm{H}_{2}$ was fed into the methanol synthesis reactor after removing the water. Methanol yield become high if the conversion of $\mathrm{CO}_{2}$ to $\mathrm{CO}$ in the RWGSR is high because the CO can react with water on the methanol synthesis catalyst. chemically removing the water on the catalyst and forwardly driving methanol synthesis reaction. Therefore. the development of an active and stable catalyst for the RWGSR was important for the CAMERE process.

The water-gas-shift reaction has been intensively studied for the last several decades for $\mathrm{H}_{2}$ production from synthesis gas. On the contrary. a reverse-water-gas-shift reaction has attracted little attention because of little demand. The $\mathrm{Fe}_{2} \mathrm{O}_{3} /$ $\mathrm{Cr}_{2} \mathrm{O}_{3}$ catalyst is a well-known commercial catalyst for the water-gas-shift reaction. ${ }^{\circ}$ The commercial cataly'st. $\mathrm{Fe}_{2} \mathrm{O}_{3} /$ $\mathrm{Cr}_{2} \mathrm{O}_{3}$. was a logical candidate for the RWGSR of the CAMERE process. But the $\mathrm{Fe}_{2} \mathrm{O}_{3} / \mathrm{Cr}_{3} \mathrm{O}_{3}$ cataly'st was easily reduced into the iron metal under high reaction temperature for the RWGSR. ${ }^{7}$ clogging the reactor with carbon formation on the metal.

In this paper. we reported the activities of the $\mathrm{ZnO}, \mathrm{Al}_{2} \mathrm{O}_{3}$.

Corresponding Author. Phone: +82-2-958-5215, Fax: +82-2958-5219, e-mail: joocatakist.re.kr and $\mathrm{ZnO} / \mathrm{Al}_{2} \mathrm{O}_{3}(\mathrm{Zn}: \mathrm{Al}=1: 2)$ catalysts examined for the RWGSR. The $\mathrm{ZnO}$ showed the highest specific activity but the catalyst was easily deactivated. It was found that $\mathrm{ZnAl}_{2} \mathrm{O}_{4}$ phase only showed good stability at the high reaction temperature for the RWGSR.

\section{Experimental Section}

$\mathrm{ZnO} . \mathrm{Al}_{2} \mathrm{O}_{3}$, and $\mathrm{ZnO} / \mathrm{Al}_{2} \mathrm{O}_{3}(\mathrm{Zn}: \mathrm{Al}=1: 2)$ catalysts were prepared by a co-precipitation of the corresponding metal nitrates $\left(\mathrm{Zn}\left(\mathrm{NO}_{2}\right)_{2}\right.$. $\mathrm{Al}\left(\mathrm{NO}_{3}\right)_{3}$ : Kanto Chemical Co. Inc.) at $\mathrm{pH} 7 .^{\S}$ The cataly sts were calcined at 500 or $8500^{\circ} \mathrm{C}$ for $3 \mathrm{hr}$. which were described in the form of catalysts $(500$ or 850 $\left.{ }^{\circ} \mathrm{C}\right)$. The activities of the catalysts were studied for the RWGSR at the temperature range of $400-700^{\circ} \mathrm{C}$ with GHSV $\left(\mathrm{mL} / \mathrm{g}_{\text {cat }} \mathrm{h}\right)$ of 15.000 . The stability of the $\mathrm{ZnO}$ and $\mathrm{ZnO} /$ $\mathrm{Al}_{2} \mathrm{O}_{3}$ catalysts $\left(850^{\circ} \mathrm{C}\right.$ ) was evaluated under the severe reaction conditions of 600 and $700^{\circ} \mathrm{C}$ and GHSV of 150.000 . The catalyst charged in a tubular reactor was heated up to the reaction temperature in the presence of $\mathrm{CO}_{2}$ and $\mathrm{H}_{2}$ before the RWGSR. The RWGSR was carried out at atmosphere pressure with the $\mathrm{H}_{2} / \mathrm{CO}_{2}$ ratio of 3 in the reactant gas. The exit gas was monitored with a gas chromatograph (Shimadzu $8 \mathrm{~A}$ instrument with a TCD. Porapak Q column $1 / 8^{\prime \prime}$ o.d. $3 \mathrm{~m}$ long in program temperature mode for analỵsis of $\mathrm{CO} . \mathrm{CO}_{2}$. $\mathrm{H}_{2}, \mathrm{CH}_{4}$ and $\mathrm{H}_{2} \mathrm{O}$ ).

The BET surface areas of the cataly sts were measured by ASAP 2000 (Micromeritics). The bulk structure of the $\mathrm{ZnO}$. $\mathrm{Al}_{2} \mathrm{O}_{3}$. and $\mathrm{ZnO} / \mathrm{Al}_{2} \mathrm{O}_{3}$ cataly sts was examined using a XRD and an electron microscopy. The X-ray powder diffraction patterns were recorded by a Rigaku D-Max-IIIA diffractometer with CuK $\alpha$ radiation. TEM \& E.D. $(200 \mathrm{kV})$ inages of the used catalysts were obtained by a Phillips CM-30 scanning transmission electron microscopy. The specimen was prepared by making the suspension of a cataly st sample and then. dipping a carbon grid with holes into the suspension and drying the carbon grid. TPR (Temperature Programmed Reduction) experimental was conducted in a 


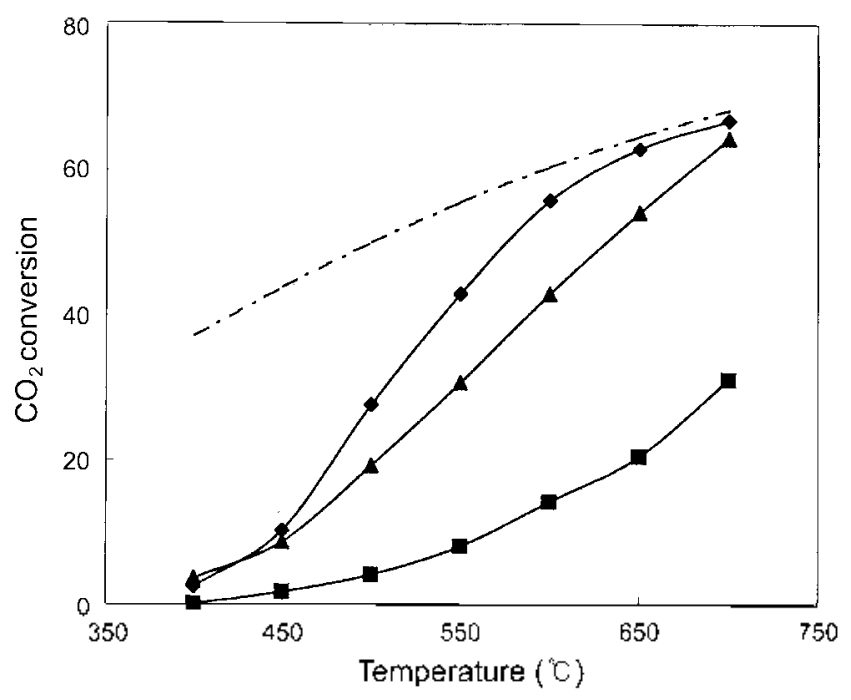

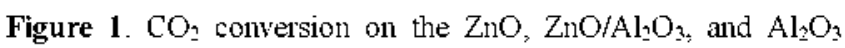
catalysts $\left(500^{\circ} \mathrm{C}\right)$. GHSV $=15,000, \cdots$. Equil, $\bullet: \mathrm{ZnO}, \mathbf{\square}: \mathrm{Al}_{2} \mathrm{O}_{3}$, A : $\mathrm{ZnO} / \mathrm{Al}_{2} \mathrm{O}_{3}$.

tubular reactor in a stream of $5 \% \mathrm{H} / \mathrm{Ar}$ with $20^{\circ} \mathrm{C} / \mathrm{min}$ of a ramping rate. The amount of $\mathrm{H}_{2}$ consumption was monitored using a TCD.

\section{Results and Discussion}

The activities of the $\mathrm{ZnO} . \mathrm{Al}_{2} \mathrm{O}_{3}$, and $\mathrm{ZnO} / \mathrm{Al}_{2} \mathrm{O}_{3}$ cataly sts were tested for the reverse-water-gas-shift reaction (RWGSR). Figure 1 showed the activities for the catalysts $\left(500^{\circ} \mathrm{C}\right)$. The $\mathrm{ZnO}\left(500^{\circ} \mathrm{C}\right)$ showed nearly equilibrium conversion at 650 ${ }^{\circ} \mathrm{C}$ and the conversion of the $\mathrm{ZnO} / \mathrm{Al}_{2} \mathrm{O}_{3}$ catalyst $\left(500^{\circ} \mathrm{C}\right.$ ) approached to the equilibrium above $700^{\circ} \mathrm{C}$. The $\mathrm{Al}_{2} \mathrm{O}_{3}$ showed the lowest activity among the three catalysts for the RWGSR. which was about one third of $\mathrm{ZnO}$. Methane (byproduct) was not detected in the reaction.

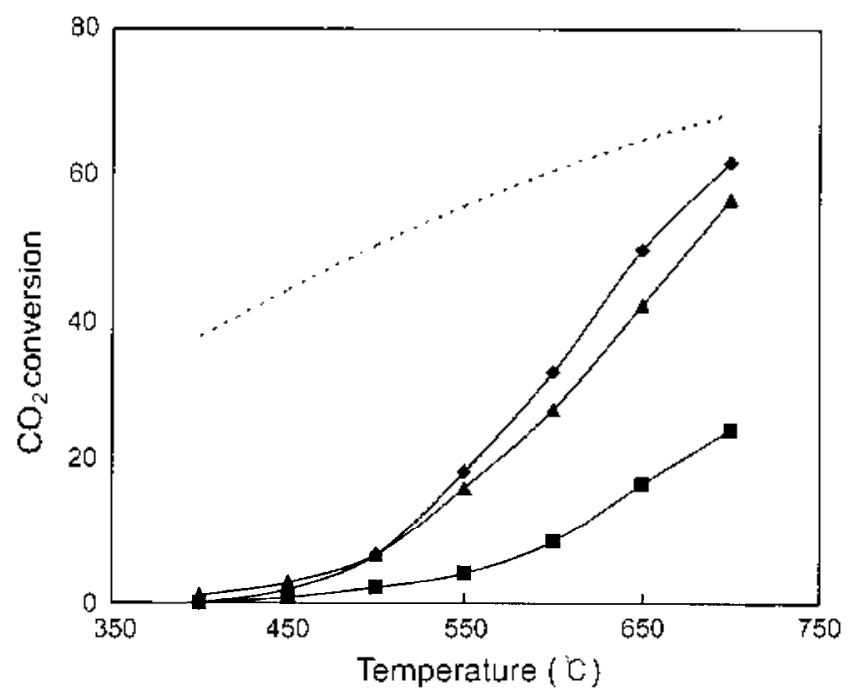

Figure 2. $\mathrm{CO}_{2}$ conversion on the $\mathrm{ZnO}, \mathrm{ZnO} / \mathrm{Al}_{2} \mathrm{O}_{3}$, and $\mathrm{Al}_{2} \mathrm{O}_{3}$ catalysts $\left(850^{\circ} \mathrm{C}\right.$ ). GHSV $=15,000$. --.: Equil, $\bullet: \mathrm{ZnO}, \mathbf{\square}: \mathrm{Al}_{2} \mathrm{O}_{3}$, $\wedge: \mathrm{ZnO}_{\mathrm{Al}} \mathrm{O}_{3}$.

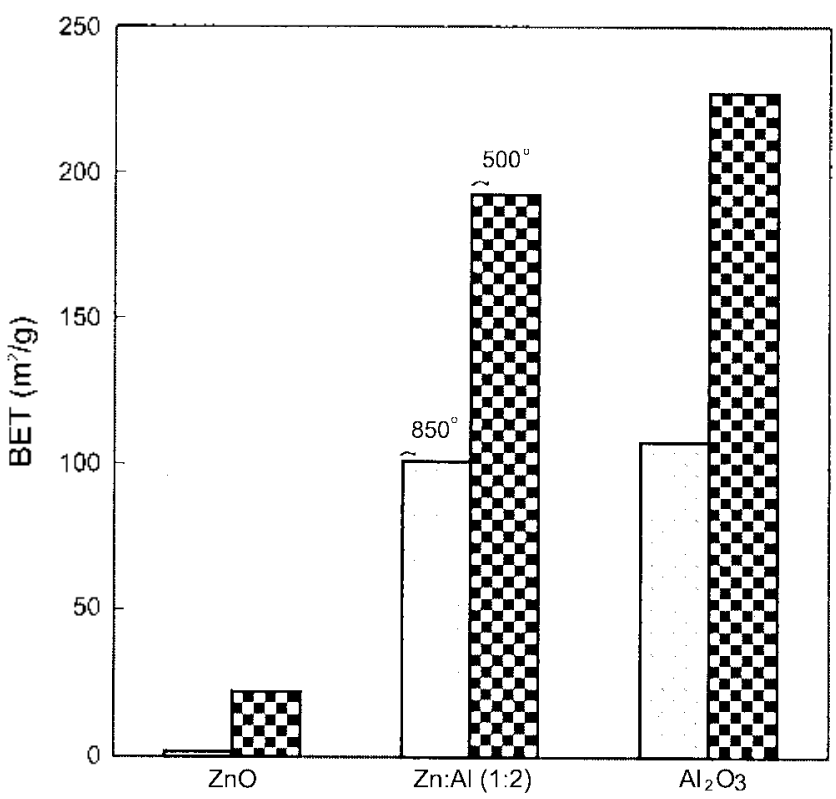

Figure 3. BET surface area of $\mathrm{ZnO}, \mathrm{ZnO} / \mathrm{Al}_{2} \mathrm{O}_{3}$, and $\mathrm{Al}_{2} \mathrm{O}_{3}$ catalysts depending on the calcination temperature.

Figure 2 indicated the activities for the catalysts $\left(850^{\circ} \mathrm{C}\right)$. Figure 3 showed the BET surface area of the catalysts depending on the calcination temperature. The calcination at $850^{\circ} \mathrm{C}$ decreased the BET surface area and also the activities for the RWGSR. The surface area of the $\mathrm{ZnO} / \mathrm{Al}_{2} \mathrm{O}_{3}$ catalysts $\left(500\right.$ or $850^{\circ} \mathrm{C}$ ) was a little smaller than those of $\mathrm{Al}_{2} \mathrm{O}_{3}\left(500\right.$ or $850^{\circ} \mathrm{C}$ ) but the activities were much higher than those of the $\mathrm{Al}_{2} \mathrm{O}_{3}$. The activity of the $\mathrm{ZnO} / \mathrm{Al}_{2} \mathrm{O}_{3}$ catalysts $\left(850^{\circ} \mathrm{C}\right)$ decreased into the $41.7 \% \mathrm{CO}_{2}$ conversion from the $54 \%$ conversion on the $\mathrm{ZnO} / \mathrm{Al}_{2} \mathrm{O}_{3}$ cataly st $(500$ ${ }^{\circ} \mathrm{C}$ ) at the reaction temperature of $650^{\circ} \mathrm{C}$. With calcination at $850^{\circ} \mathrm{C}$. the activity of the $\mathrm{Zn} / \mathrm{Al}_{2} \mathrm{O}_{3}$ cataly st decreased about $12 \%$ at the reaction temperature of $650^{\circ} \mathrm{C}$. whereas the BET surface area of the $\mathrm{ZnO} / \mathrm{Al}_{2} \mathrm{O}_{3}$ cataly'st decreased from 192.5 to $108.0 \mathrm{~m}^{2} / \mathrm{g}_{\mathrm{c} a t}$. The $\mathrm{ZnO}$ gave good specific activity as compared with the $\mathrm{ZnO} / \mathrm{Al}_{2} \mathrm{O}_{2}$ and the $\mathrm{Al}_{2} \mathrm{O}_{3}$ catalysts. The $\mathrm{CO}_{2}$ conversion of $62.7 \%$ on the $\mathrm{ZnO}\left(500^{\circ} \mathrm{C}\right.$ ) decreased into the $49.4 \%$ on the $\mathrm{ZnO}\left(850^{\circ} \mathrm{C}\right)$ at the reaction temperature of $650^{\circ} \mathrm{C}$. On the other hand. the BET surface area of the $\mathrm{ZnO}$ catalyst decreased from 22.0 to $1.5 \mathrm{~m}^{2} / \mathrm{g}_{\mathrm{cat}}$. However. it is interesting to mention that the $\mathrm{ZnO}$ catalyst ( 850 $\left.{ }^{\circ} \mathrm{C}\right)$ showed the lugh specific activity:

The CAMERE process consists of a reverse-water-gasshift reaction (RWGSR) and a methanol synthesis reaction." The conversion of $\mathrm{CO}_{2}$ into $\mathrm{CO}$ in the reverse-water-gasshift reactor should be increased as high as possible. Then. the feed gas with high $\mathrm{CO}$ concentration from the reverse water-gas-shift reactor into the methanol synthesis reactor could result in the high methanol yield. The conventional active oxide catalysts for the RWGSR were mostly reduced at the high temperature above $400{ }^{\circ} \mathrm{C}$ and then. deactivated. ${ }^{7}$ Therefore, the stable catalysts even with a little bit lower activity should be important for the RWGSR in the CAMERE process. Although the $\mathrm{ZnO}$ catalyst showed good specific activities for the RWGSR, the $\mathrm{ZnO}\left(500\right.$ or $\left.850^{\circ} \mathrm{C}\right)$ 


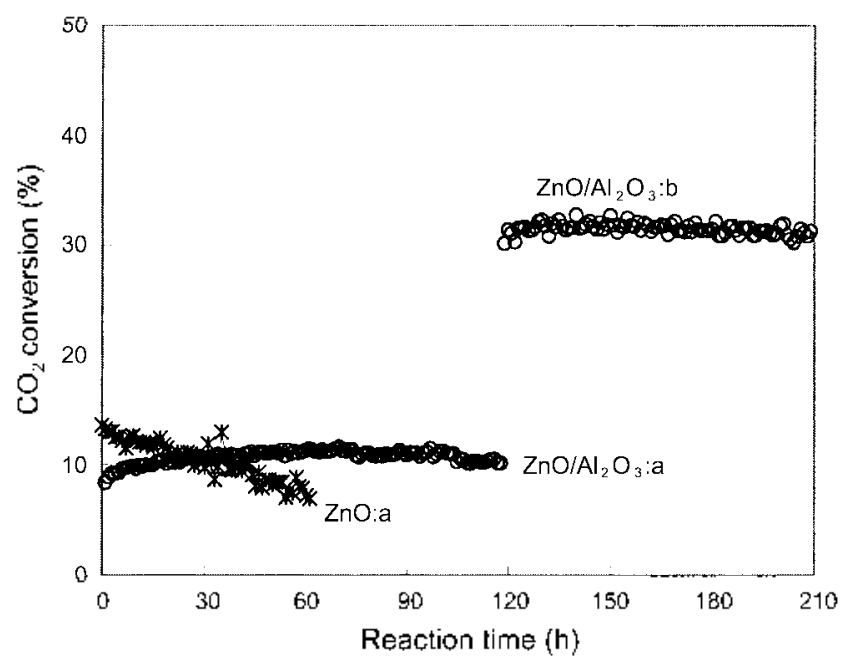

Figure 4. $\mathrm{CO}_{2}$ conversion on the $\mathrm{ZnO}$ and $\mathrm{ZnO}_{\mathrm{An}} \mathrm{O}_{2} \mathrm{O}_{3}$ catalysts $\left(850^{\circ} \mathrm{C}\right)$ with the reaction time at the GHSV of 150,000 . a: reaction temp. of $873 \mathrm{~K}$, b: reaction temp. of $973 \mathrm{~K}$.

was reduced from 500 to $1000{ }^{\circ} \mathrm{C}$ depending on the calcination temperature ${ }^{9.16}$ causing the catalyst deactivation. The $\mathrm{ZnO} / \mathrm{Al}_{2} \mathrm{O}_{3}$ catalyst $\left(500^{\circ} \mathrm{C}\right)$ was also deactivated with reaction time at reaction temperature of $600^{\circ} \mathrm{C}$. The life test was performed on the $\mathrm{ZnO}$ and $\mathrm{ZnO} / \mathrm{Al}_{2} \mathrm{O}_{3}$ catalysts $(850$ ${ }^{\circ} \mathrm{C}$ ) at GHSV of 150.000 and $600{ }^{\circ} \mathrm{C}$ and then. $700{ }^{\circ} \mathrm{C}$ to confirm the stability in a short time as shown in the Figure 4. The $\mathrm{ZnO}\left(850^{\circ} \mathrm{C}\right)$ was gradually deactivated with reaction time. Only $\mathrm{ZnO} / \mathrm{Al}_{2} \mathrm{O}_{3}$ cataly'st $\left(850^{\circ} \mathrm{C}\right)$ did not deactivate at the reaction temperature of 600 and $700^{\circ} \mathrm{C}$. A catalyst life for a day with GHSV of 150,000 meant that the catalyst would be operated for 50 day's in the real system operated at the GHSV of 3.000. Therefore. the $\mathrm{ZnO} / \mathrm{Al}_{2} \mathrm{O}_{3}$ cataly'st $(850$ $\left.{ }^{\circ} \mathrm{C}\right)$ would be durable more than one year in the reaction conditions of the CAMERE process. The conventional oxide catalysts for the RWGSR were reduced at high reaction temperature above $400^{\circ} \mathrm{C}$ and then. by'-product of methane made even at atmosphere pressure. ${ }^{6.7}$ But. the methane was not produced on the $\mathrm{ZnO} / \mathrm{Al}_{3} \mathrm{O}_{3}$ catalyst $\left(850^{\circ} \mathrm{C}\right)$ even at 5 atm because the catalyst was not reduced into the metal. The $\mathrm{ZnO} / \mathrm{Al}_{2} \mathrm{O}_{3}$ catalyst $\left(850^{\circ} \mathrm{C}\right)$ did not deactivate for the reaction time of $210 \mathrm{hrs}$ even at $700^{\circ} \mathrm{C}$ as shown in the Figure 4.

The structure of the $\mathrm{ZnO}$. $\mathrm{Al}_{2} \mathrm{O}_{3}$. and $\mathrm{ZnO} / \mathrm{Al}_{2} \mathrm{O}_{3}$ cataly sts $\left(850^{\circ} \mathrm{C}\right)$ was monitored by XRD. The XRD patterns were shown in the Figure 5. The $\mathrm{Al}_{2} \mathrm{O}_{3}\left(500^{\circ} \mathrm{C}\right)$ did not show any crystalline structure but the $\mathrm{Al}_{2} \mathrm{O}_{3}\left(850^{\circ} \mathrm{C}\right)$ show a little crystalline structure like in the spectrum in the Figure 5. On the other hand. the $\mathrm{ZnO}$ and $\mathrm{ZnO} / \mathrm{Al}_{2} \mathrm{O}_{3}$ cataly sts $\left(850^{\circ} \mathrm{C}\right)$ showed good crystalline structure. Figure 5 showed that the $\mathrm{ZnO} / \mathrm{Al}_{2} \mathrm{O}_{3}$ catalyst $\left(850^{\circ} \mathrm{C}\right)$ was the spinel structure of $\mathrm{ZnAl}_{2} \mathrm{O}_{4}$, which was monitored by the XRD.

Figure 6 indicated the TEM images and the electron diffraction pattern of the $\mathrm{ZnO}$ and $\mathrm{ZnO} / \mathrm{Al}_{2} \mathrm{O}_{3}$ catalysts depending on the calcination temperature of 500 or $850^{\circ} \mathrm{C}$. TEM images showed that the particle size of the $\mathrm{ZnO}$ ( 500 $\left.{ }^{\circ} \mathrm{C}\right)$ about $100 \mathrm{~nm}$ was sintered into the larger particle than

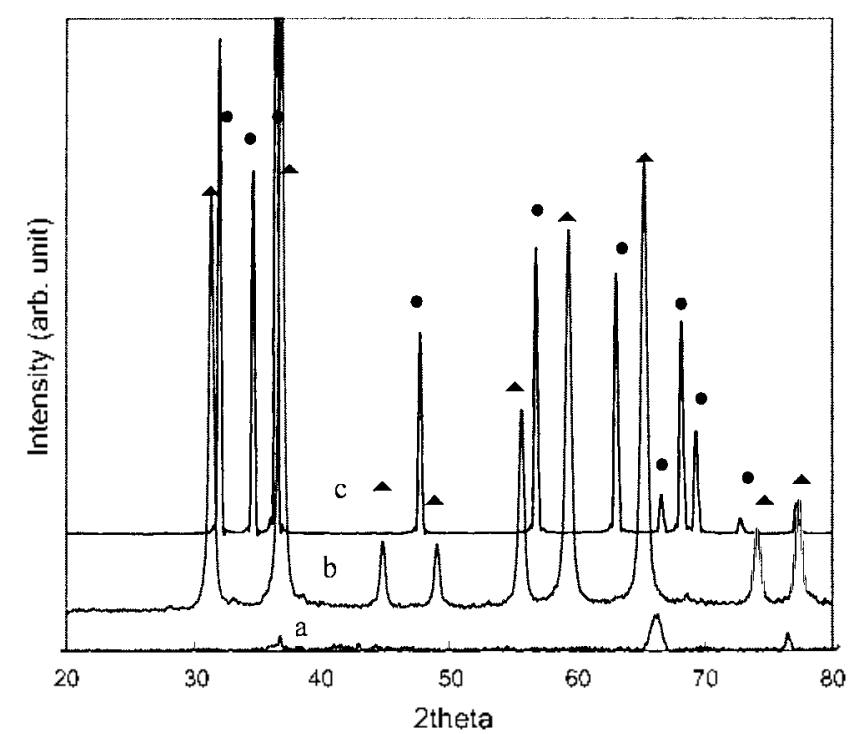

Figure 5. XRD spectra of the $\mathrm{Al}_{2} \mathrm{O}_{3}, \mathrm{ZnO} / \mathrm{Al}_{2} \mathrm{O}_{3}$, and $\mathrm{ZnO}$ catalysts $\left(850^{\circ} \mathrm{C}\right.$ ) a: $\mathrm{Al}_{2} \mathrm{O}_{3}$ b: $\mathrm{ZnO} / \mathrm{Al}_{2} \mathrm{O}_{3}$ c: $\mathrm{ZnO} ;: \mathrm{ZnAl}_{2} \mathrm{O}_{4} \bullet: \mathrm{ZnO}$.

$500 \mathrm{~nm}$ by the heat treatment at $850^{\circ} \mathrm{C}$. The scattered spots of the $\mathrm{ZnO}\left(500^{\circ} \mathrm{C}\right)$ were shown by the electron diffraction for the selected area including a few number of $\mathrm{ZnO}(500$ $\left.{ }^{\circ} \mathrm{C}\right)$ particles. The approximate $d$ values could be calculated from the radius of the electron diffraction for the $\mathrm{ZnO}$ (500 ${ }^{\circ} \mathrm{C}$ ) as shown in Table 1. although the ring pattern was not so clear due to a small number of particles. The interplanar spacings $d$ values were calculated by the basic equation $d=$ $\lambda \mathrm{L} / \mathrm{R}$ from the distance $\mathrm{R}$ of the diffraction spot from the origin. ${ }^{11}$ Where. $\lambda$ was $0.02508 \AA$ at $200 \mathrm{kV}$. L was $300 \mathrm{~mm}$. The calculated $d$ values were coincided with the $d$ values of the crystalline structure of the $\mathrm{ZnO}$. The electron diffraction for a particle of the $\mathrm{ZnO}\left(850^{\circ} \mathrm{C}\right)$ was obtained. The spots indicated that the $\mathrm{ZnO}\left(850^{\circ} \mathrm{C}\right)$ was a single crystal. The electron diffraction pattern for the $\mathrm{ZnO}\left(850^{\circ} \mathrm{C}\right)$ was for an [101] axis. It was confirmed from the angle between the reciprocal lattice points $(101)$ and $(010)$. and the d values of (101) and (010) plane. The TEM image of the $\mathrm{ZnO} / \mathrm{Al}_{2} \mathrm{O}_{3}$ catalyst $\left(500{ }^{\circ} \mathrm{C}\right)$ was shown in (c) of the figure 6 and the $\mathrm{ZnO} / \mathrm{Al}_{2} \mathrm{O}_{3}$ catalyst $\left(500^{\circ} \mathrm{C}\right)$ did not make a uniform phase. Two phases of $\mathrm{ZnO}$ and $\mathrm{ZnAl}_{2} \mathrm{O}_{4}$ were confirmed from the $\mathrm{d}$ values of the radius of the electron diffraction pattern. The $\mathrm{ZnAl}_{2} \mathrm{O}_{4}$ phase in the $\mathrm{ZnO} / \mathrm{Al}_{-} \mathrm{O}_{3}$ catalyst $\left(500^{\circ} \mathrm{C}\right.$ ) was also confirmed by the XRD but the intensity was not strong as compared with that in the $\mathrm{ZnO} / \mathrm{Al}_{2} \mathrm{O}_{3}$ catalyst $\left(850^{\circ} \mathrm{C}\right.$ ). Moreover. the excess $\mathrm{Al}_{2} \mathrm{O}_{3}$ phase in the $\mathrm{ZnO} / \mathrm{Al}_{2} \mathrm{O}_{3}$ catalyst $\left(500^{\circ} \mathrm{C}\right.$ ) could not be discriminated from the $\mathrm{ZnAl}_{2} \mathrm{O}_{4}$ phase by the XRD. The TEM image and the electron diffraction pattern of the $\mathrm{ZnO} / \mathrm{Al}_{2} \mathrm{O}_{3}$ catalyst $\left(850^{\circ} \mathrm{C}\right)$ were shown in (d) of the Figure 6.

The TEM image indicated that the $\mathrm{ZnO} / \mathrm{Al}_{2} \mathrm{O}_{3}$ catalyst $\left(850^{\circ} \mathrm{C}\right)$ made a uniform phase. The calculated $d$ values from the radius of the electron diffraction pattern for the $\mathrm{ZnO} / \mathrm{Al}_{2} \mathrm{O}_{3}$ catalyst $\left(850^{\circ} \mathrm{C}\right)$ were coincided with the $d$ values of the $\mathrm{ZnAl}_{2} \mathrm{O}_{4}$ crystalline structure. The electron diffraction pattern for the $\mathrm{ZnO} / \mathrm{Al}_{2} \mathrm{O}_{3}$ catalyst $\left(850^{\circ} \mathrm{C}\right)$ 


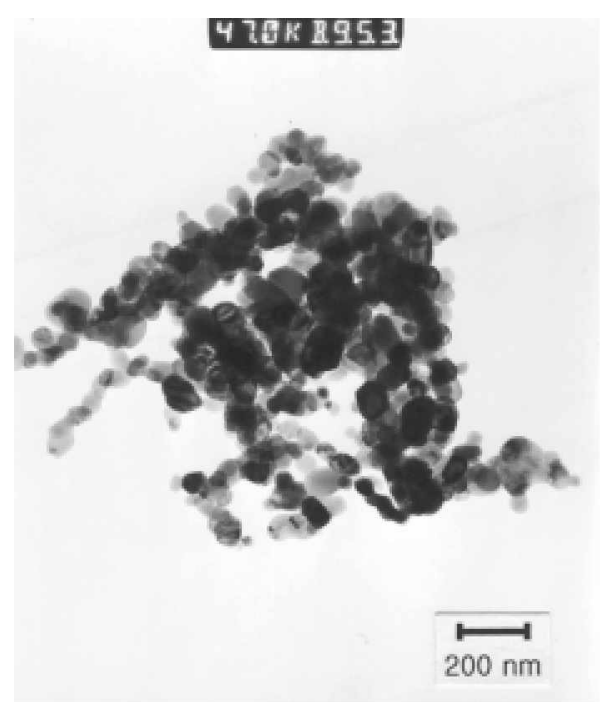

(a)

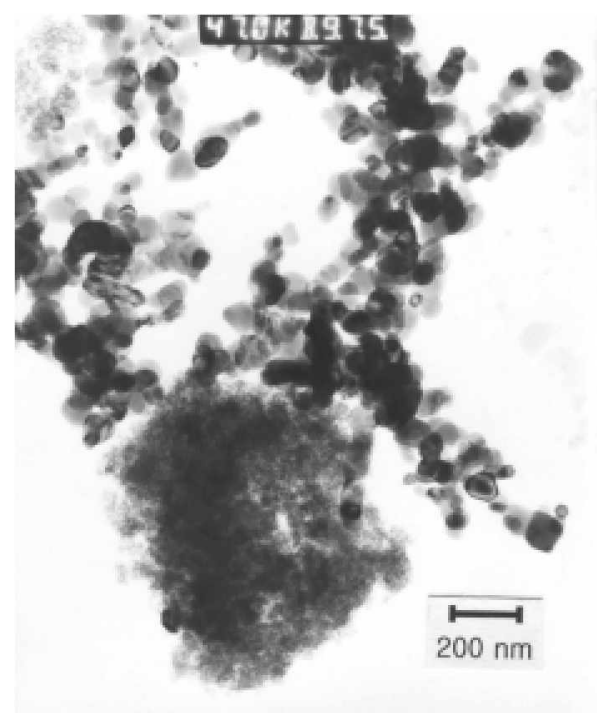

(c)

\section{एस6 R9ב2}

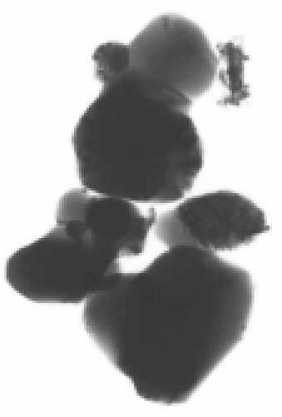

$500 \mathrm{~nm}$

(b)

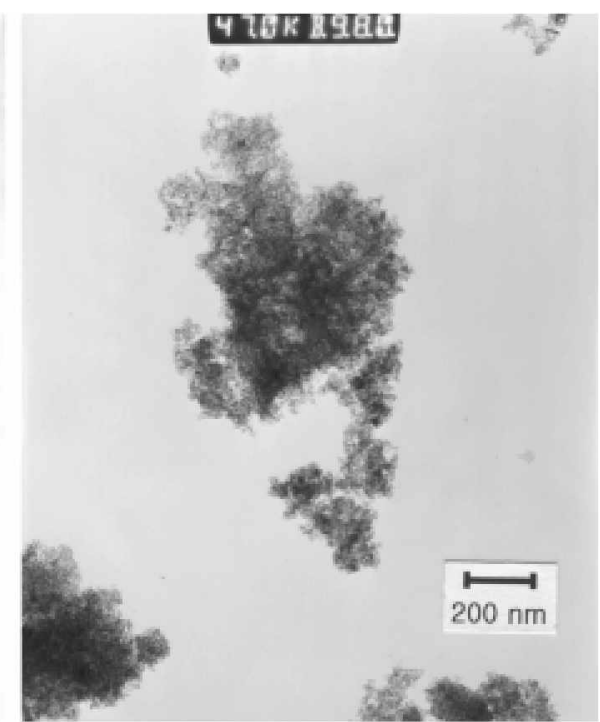

(d)

Figure 6. TEM images and electron diffraction patterns of the $\mathrm{ZnO}$ and $\mathrm{ZnO} / \mathrm{Al}_{2} \mathrm{O}_{3}$ catalysts depending on the calcination temperature. a: $\mathrm{ZnO}\left(500^{\circ} \mathrm{C}\right)$, b: $\left.\mathrm{ZnO}(850)^{\circ} \mathrm{C}\right), \mathrm{c}: \mathrm{ZnO} / \mathrm{Al}_{2} \mathrm{O} \mathrm{O}_{3}\left(500^{\circ} \mathrm{C}\right)$, d: $\mathrm{ZnO} / \mathrm{Al}_{2} \mathrm{O}_{3}\left(850^{\circ} \mathrm{C}\right)$

Table 1. Comparison the $d$ values of $\mathrm{ZnO}$ and $\mathrm{ZnAl}_{2} \mathrm{O}_{+}$crystalline structure with the calculated $d$ values from the radius of the electron diftraction pattem

\begin{tabular}{|c|c|c|c|}
\hline \multicolumn{2}{|c|}{$2 n 10$} & \multicolumn{2}{|c|}{$\mathrm{Zn} \mathrm{Al}_{\curvearrowright} \mathrm{O}_{4}$} \\
\hline$d$ values & $\begin{array}{l}\text { Calculated } d \\
\text { values }\end{array}$ & $d$ values & $\begin{array}{l}\text { Calculated } d \\
\text { values }\end{array}$ \\
\hline $2.814(57)$ & 2.894 & $2.861(84)$ & 2.894 \\
\hline $2.603(44)$ & 2.594 & $2.438(100)$ & 2.427 \\
\hline $2.476(100)$ & 2.508 & $1.855(10)$ & 1.980 \\
\hline $1.911(23)$ & 1.929 & $1.650(24)$ & 1.635 \\
\hline $1.6247(32)$ & 1.635 & $1.556(40)$ & 1.472 \\
\hline & & $1.429(43)$ & 1.419 \\
\hline
\end{tabular}

showed the distinct ring pattem. which meant the $\mathrm{ZnO} /$ $\mathrm{Al}_{2} \mathrm{O}_{3}$ catalyst $\left(850^{\circ} \mathrm{C}\right.$ ) had good crystalline structure. The calculated $d$ values of $\mathrm{ZnO} / \mathrm{Al}_{-} \mathrm{O}_{3}$ were compared with the $d$ values of the $\mathrm{ZnAl}_{2} \mathrm{O}_{4}$ cry'stalline structure in the Table 1 .
The $\mathrm{ZnO} / \mathrm{Al}_{2} \mathrm{O}_{2}$ catalyst $\left(500^{\circ} \mathrm{C}\right.$ ) showed good activity than the $\mathrm{Zn} / \mathrm{Al}_{2} \mathrm{O}_{4}$ cataly st $\left(850^{\circ} \mathrm{C}\right)$ as shown in the Figure 1 and 2 . But the $\mathrm{ZnO} / \mathrm{Al}_{2} \mathrm{O}_{3}$ catalyst $\left(500^{\circ} \mathrm{C}\right.$ ) lost the activity with the reaction time at the temperature of $600^{\circ} \mathrm{C}$ because most $\mathrm{ZnO}$ in the $\mathrm{ZnO} / \mathrm{Al}_{2} \mathrm{O}_{3}$ catalyst $\left(500^{\circ} \mathrm{C}\right.$ ) did not form the $\mathrm{ZnAl}_{2} \mathrm{O}_{4}$ phase and the $\mathrm{ZnO}$ and $\mathrm{ZnAl}_{2} \mathrm{O}_{4}$ phase were separated in the $\mathrm{ZnO} / \mathrm{Al}_{2} \mathrm{O}_{3}$ catalyst. Only $\mathrm{ZnAl}_{2} \mathrm{O}_{4}$ phase was stable for the RWGSR and the spinel structure of $\mathrm{ZnAl}_{2} \mathrm{O}_{4}$ in the $\mathrm{ZnO} / \mathrm{Al}_{2} \mathrm{O}_{3}$ catalyst $\left(850^{\circ} \mathrm{C}\right)$ was confimed by XRD and electron diffraction. As previously suggested. the high stability of $\mathrm{ZnAl}_{2} \mathrm{O}_{4}$ for the RWGSR could be related to the reducibility of the catalyst sample. TPR (temperature progranmmed reduction) in $5 \% \mathrm{H}_{2} / \mathrm{Ar}$ was conducted to investigate the reducibility of $\mathrm{ZnO}\left(850^{\circ} \mathrm{C}\right)$ and $\mathrm{Zn}_{1} / \mathrm{Al}_{2} \mathrm{O}_{4}\left(850^{\circ} \mathrm{C}\right)$. The $\mathrm{ZnO}\left(850^{\circ} \mathrm{C}\right)$ started to be reduced at $750^{\circ} \mathrm{C}$. While the $\mathrm{Zn} / \mathrm{Al}_{2} \mathrm{O}_{4}\left(850^{\circ} \mathrm{C}\right.$ ) was not reduced up to $1100^{\circ} \mathrm{C}$. Therefore the stability of the $\mathrm{Zn}$ / $\mathrm{Al}_{2} \mathrm{O}_{4}\left(850^{\circ} \mathrm{C}\right)$ was enhanced by the formation of the 


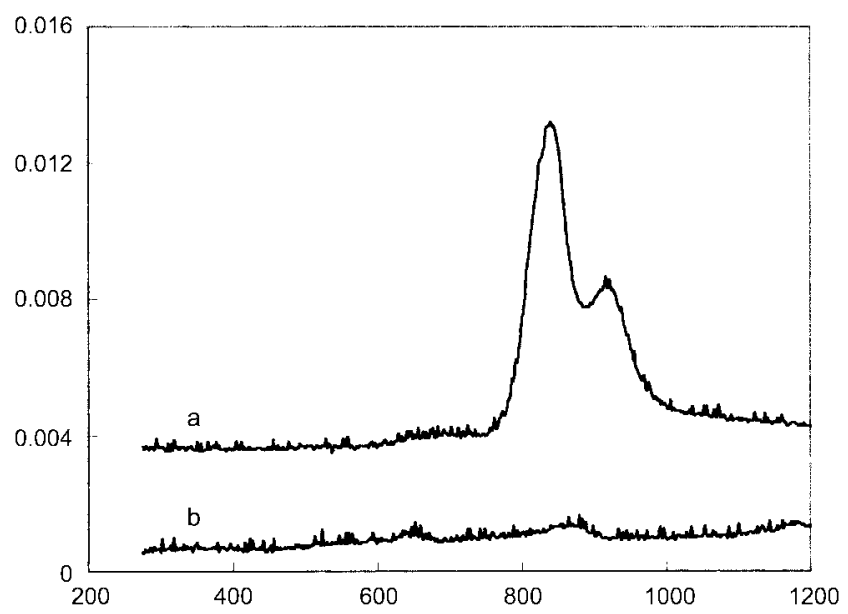

Figure 7. Temperature programmed reduction of $\mathrm{ZnO}$ and $\mathrm{ZnO}$ $\mathrm{Al}_{2} \mathrm{O}_{3}\left(850^{\circ} \mathrm{C}\right)$ in a stream of $5 \% \mathrm{H}_{2} / \mathrm{Ar}$. a: $\mathrm{ZnO}\left(850^{\circ} \mathrm{C}\right)$, b: $\mathrm{ZnO}$ $\mathrm{Al}_{2} \mathrm{O}_{3}\left(850^{\circ} \mathrm{C}\right)$.

$\mathrm{ZnAl}_{2} \mathrm{O}_{4}$ spinel structure as compared with that of the $\mathrm{ZnO}$. while the activity of the $\mathrm{Zn} / \mathrm{Al}_{2} \mathrm{O}_{4}\left(850^{\circ} \mathrm{C}\right)$ was increased by the $\mathrm{ZnO}$ component as compared with that of the $\mathrm{Al}_{2} \mathrm{O}_{3}$.

\section{Conclusions}

The $\mathrm{ZnO} / \mathrm{Al}_{2} \mathrm{O}_{3}$ catalyst $\left(850^{\circ} \mathrm{C}\right)$ was made of the spinel structure of $\mathrm{ZnAl}_{2} \mathrm{O}_{4}$. which was confirmed by $\mathrm{XRD}$ and electron diffraction. The $\mathrm{ZnAl}_{2} \mathrm{O}_{4}$ cataly st was stable till 210 hrs under 600 and $700^{\circ} \mathrm{C}$ and GHSV of 150,000 . although the activity was less than those of the $\mathrm{ZnO}$ and the $\mathrm{ZnO}$ / $\mathrm{Al}_{2} \mathrm{O}_{3}$ catalysts $\left(500^{\circ} \mathrm{C}\right)$. Whereas. the $\mathrm{ZnO}\left(850^{\circ} \mathrm{C}\right)$ was gradually deactivated with the reaction time. even though the cataly'st had the high specific activity for the RWGSR

Acknowledgment. This research was performed for the clean energy technology development. funded by $R \& D$ Management Center for Energy and Resources of Korea Energy Management Corporation.

\section{References}

1. Jessop. P. G.; Ihariya. T.; Noyori, R. Chentical Reviews 1995. 95(2). 259.

2. Usui. N.: Ikenouchi. M. Energv Conwrs. 1/gmt. 1997. 38. \$487S492.

3. Kitamura. N.: Tazuke, S. Chent Lett. 1983. 1109.

4. Lee. K. R.: Lim. J. H.: Lee. J. K.: Chun. H. S. Korean J. Chent. Eng. 1999, J6(6), 829 .

5. Joo. O. S.: Jung. K. D.: Moon. I.: Rozorskii. A. Ya: Lin. G. I.: Han1. S. H.: Uhm. S. J. Ind Eng. Chem. Res. 1999. 38(5). 1808.

6. Twigg. M. V. Catalyst Handbook: Wolfe Publicationi: London. 1989: pp 283-339.

7. Park, S. W: Joo, O. S.: Jung. K. D.: Kim. H: Han, S. H. Korean J. Chent. Eng. 2000, $17(6) .719$.

8. Joo. O. S.: Jung. K. D.: Han. S. H.: Unm. S. T.: Lee. D. K.: Ihm. S. K. Appl Catal A: General 1996. 135. 273.

9. Park. S. W.: Joo. O. S.: Jung. K. D.: Kim. H.: Han1. S. H. Appt. Catal. A: General 2001. 211.81.

10. Jung. K. D.: Joo. O. S.: Han, S. H. Catal. Lent 2000. 68, 49

11. Heimendahl. M. V. Electron Mifroscopv of Materials. Academic Press: New York, U.S.A. 1980; p 95. 